\title{
Impact assessment of heavy metals pollution of Vartur lake, Bangalore
}

\author{
Aboud S. Jumbe and N. Nandini* \\ Department of Environmental Science, Bangalore University, Jnanabharathi Campus, Bangalore - 560056, INDIA \\ *Correspnding author. E-mail: nandini.sai@ rediffmail.com
}

\begin{abstract}
The unscientific disposal of wastes and pollution in urban water bodies has caused immense problems not only to human beings but also to the aquatic biodiversity. Assessment of heavy metals in Vartur Lake, Bangalore, revealed that Cadmium (Cd), Cobalt (Co), Chromium (Cr), Nickel (Ni), and Lead ( $\mathrm{Pb}$ ) all exceeded drinking water standards. Nevertheless, Chromium (Cr) exceeded the CPCB's tolerance limits for water bodies subjected to effluent discharge. In Eichornia crassipes, Cd, Co, Cr, and Ni were critical. In the sediments, Cadmium (Cd) and Nickel (Ni) exceeded the Probable Effect Level (PEL). Sediment Geo-accumulation Index of the lake showed moderate contamination with $\mathrm{Mn}, \mathrm{Cu}$, and $\mathrm{Pb}$. $\mathrm{Cr}$ had the highest plant/sediments metal concentration factor even though its bioavailability in plants $(71.5 \mathrm{ppm})$ was lower compared to Manganese (192.3 ppm). This calls for immediate action to be implemented to carry out necessary environmental mitigation measures for the lake.
\end{abstract}

Keywords: Microwave digestion, Probable effect level, Sediment geo-accumulation index, Pollution load index

\section{INTRODUCTION}

Wetlands can be defined as land transition between terrestrial and aquatic ecosystems where the water table is usually at or near the surface or the land is covered by shallow water (Bergstrom and Stoll,1990; Satyasiba, 2007). They are life supporting systems providing fishes, forest products, agriculture, water, flood control, erosion buffering, plant gene pool, wildlife, recreation, etc and they have immense socio-economic and ecological importance (Satyasiba, 2007). However, many Indian cities are under tremendous pressure of urbanization as they are expanding more horizontally than vertically where urban sprawling is conquering the rural areas. With high population density, shortage of monsoon rainfalls, and increasing water depletion, many fresh water bodies in Indian cities are now polluted and disappearing (Karmakar, 2007). Also, Das and Acharya (2003) state that the surface water resources serve as the best sinks for the discharge of domestic as well as industrial wastes. This unscientific disposal of wastes has caused immense problems not only to human beings but also to the aquatic environment. Nowadays, The urban aquatic ecosystems are strongly influenced by long term discharge of untreated domestic and industrial wastewaters, storm water runoff, accidental spills and direct solid waste dumping (Phuong et al., 1998). Aquatic plants play a key role in protecting water quality and providing habitat. They also provide shelter for fish, wildlife, and invertebrates that in turn provide food for other organisms. They help improve water quality, protect shorelines, and lake bottoms while playing significantly in adding to aesthetic quality of the lake (Jafari,2007). They definitely play a key role in biogeochemical cycles and food webs in lake systems. They are primary producers and their metabolic activities accelerate the physico-chemical conditions of a water system. These aquatic macrophytes are also large, predominantly plants inhabiting various sections of aquatic ecosystems in different zones of life sphere (Gopal et al.,2002) within a water spread area and around the banks.

Macrophytes are known as good indicators of heavy metals contamination in aquatic ecosystems and they also act as good biofilters by accumulating heavy metals from the surrounding environment (Vardanyan et al.,2007). But aquatic macrophytes also have the tendency to bioaccumulate heavy metal residues present in water or the sediment stratum. All these released pollutants have a great ecological impact on the water quality and especially on environmental resistance of aquatic macrophytes.

In addition, Ikem et al. (2003) have characterized importance of sediments in heavy metals pollution. They state that sediments are important sinks for various pollutants like heavy metals and play a significant role in the remobilization of contaminants in aquatic systems under favorable conditions and in interactions between water and sediment. This direct transfer of chemicals from sediments to organisms is a major route of exposure for aquatic life. Heavy Metals distribute in sediments as exchangeable, carbonate bound, iron-manganese oxide bound, organic matter bound and residual bound species. The speciation of metals can be evaluated by carefully 
choosing the extracting solutions and digestion conditions. This objective of the study was to investigate the level of heavy metal contamination of water, their bioaccumulation in aquatic and wetland macrophytes located within the water spread area and on the shoreline banks, and their deposition in the bottom sediments of the Vartur Lake.

\section{MATERIALS AND METHODS}

About the study area : Vartur lake (Fig. 1) is located inside Koramangala-Challagatta Valley in the eastern periphery of Bangalore city at $12^{\circ} 56^{\prime} 49.50 \mathrm{~N}$ and $77^{\circ} 44^{\prime} 10.54 \mathrm{E}$. Vartur lake original area was 216 ha. Recently, due to erratic rainfalls, siltation and encroachment, the area has been reduced to 165.75 ha. The lake's length is estimated to be $2.1 \mathrm{~km}$ while its Breadth is $1.0 \mathrm{~km}$. The mean depth is $4 \mathrm{~m}$. The entire length of the shore line is approximately 7.23 $\mathrm{km}$. The lake lies at an elevation of $880 \mathrm{~m}$ above sea level. This lake is severely polluted due to inflow of water from a severely polluted Bellandur. The major economic activity around the lake at the present moment is still agriculture but encroachment caused by the expansion of the suburban layouts in the northern and southern banks of the catchment is exacerbating already perilous environmental conditions of this lake. In 2001 the water spread area was at 119.0 ha. The lake has been extensively covered with water hyacinth (Eichornia crassipes), an invasive and exotic species responsible for suffocation of majority of lakes of Bangalore.

Sampling and analysis strategy: The entire work of sampling and analysis of heavy metals in water, aquatic macrophytes, and in sediments was done between May 2006 and December 2007. All chemicals used were of reagent grade and distilled/de-ionized water was used throughout the experimentation. Washing procedures, sampling for heavy metals determinations, sample holding times and preservation techniques conform to standard methods for water and wastewater analysis (APHA, 1995). Procedural blanks, reagent blanks, preparation of standard solutions under clean laboratory environment, calibration of Shimadzu AAS-6300 atomic absorption spectrophotometer (AAS) using certified standards and the analyses of calibrated standards were employed as per the equipment manual.

Sampling of water: Standard methods for examination of water and waste water (APHA,1995) were employed. Surface water samples were collected seasonally in selected sampling zones $10 \mathrm{~cm}$ below the surface of the lake water (Das and Acharya, 2003) using the fresh 2-L plastic containers that had been previously washed with $1: 3 \mathrm{HNO}_{3}$. The samples were brought to laboratory for digestion and analysis.
Sampling of plants: Plant samples which were studied were water hyacinth (Eichornia crassipes). This species has been known to infest many lakes in Urban Bangalore including Vartur. Plant samples were collected from the selected sampling points corresponding to the inlet, middle, and outlet zones of the lake and kept in clean polythene bags and brought to the laboratory where they were thoroughly washed in distilled water to remove surface particles. In order to enhance the accuracy of the results, samples from within the littoral zone (McGee $e t$ $a l ., 2007)$ and immediately within the tidal line of the lake were selected. Only aerial parts of the plants were chosen and cut using stainless steel scissors. In the laboratory the samples were washed with distilled water several times (Farago and Mehra,1989) and dried at $105^{\circ} \mathrm{C}$ for 48 hours (Burton and John,1977).

Sampling of sediments: Samples of sediments were taken from along the banks of the sampling station. All samples were taken from the top $10 \mathrm{~cm}$ layer to a depth of over 30 $\mathrm{cm}$ (Pilotte et al.,1978). Sampling tools were washed and dried with water before the next sample was collected (Singh et al.,2002). The collected samples were stored in polythene plastic containers. Samples were air dried in the laboratory at room temperature, ground in fine mixture using mortar and pestle before sieved under $2 \mathrm{~mm}$ mesh (Kronfeld and Navrot,1975; Bifano and Mogollon,1995; Jose et al., 1989 and Neto et al., 2005). The samples were stored in a polythene container ready for analysis.

Microwave digestion: The accurate measurement of trace metal concentrations is an important goal in environmental monitoring and research, as many of these elements have been identified as potentially hazardous pollutants (Canadian Environmental Protection Act,1999 and Nouri et al.,2007). The use of closed vessel microwave- assisted digestion systems under high temperature and pressure for acid digestion has now become routine (Nouri et al., 2007) as it allows shorter digestion times and good recoveries, even for volatile elements. In addition, it reduces the risk of external contamination and requires smaller quantities of acids, thus improving detection limits and the overall accuracy of the analytical method (Sandroni et al.,2003 and Nouri et al., 2007). Moreover, they are safer and simpler and provide more controlled and reproducible conditions than hot plate or block digesters (Nadkarni,1984 and Nouri et al., 2007). In this study, heavy metals digestion was done using EPA Method 3015 (Ikem et al., 2003) and involved a high performance microwave assisted digestion Milestone Labstation using a 6 Monobloc Microwave Ethos D Microwave Labstation (Baron et al., 2004) - an automatic user interface system with a direct automatic temperature and pressure control of up to $300^{\circ} \mathrm{C}$ and $100 \mathrm{Bar}$ respectively under the given power reference. 


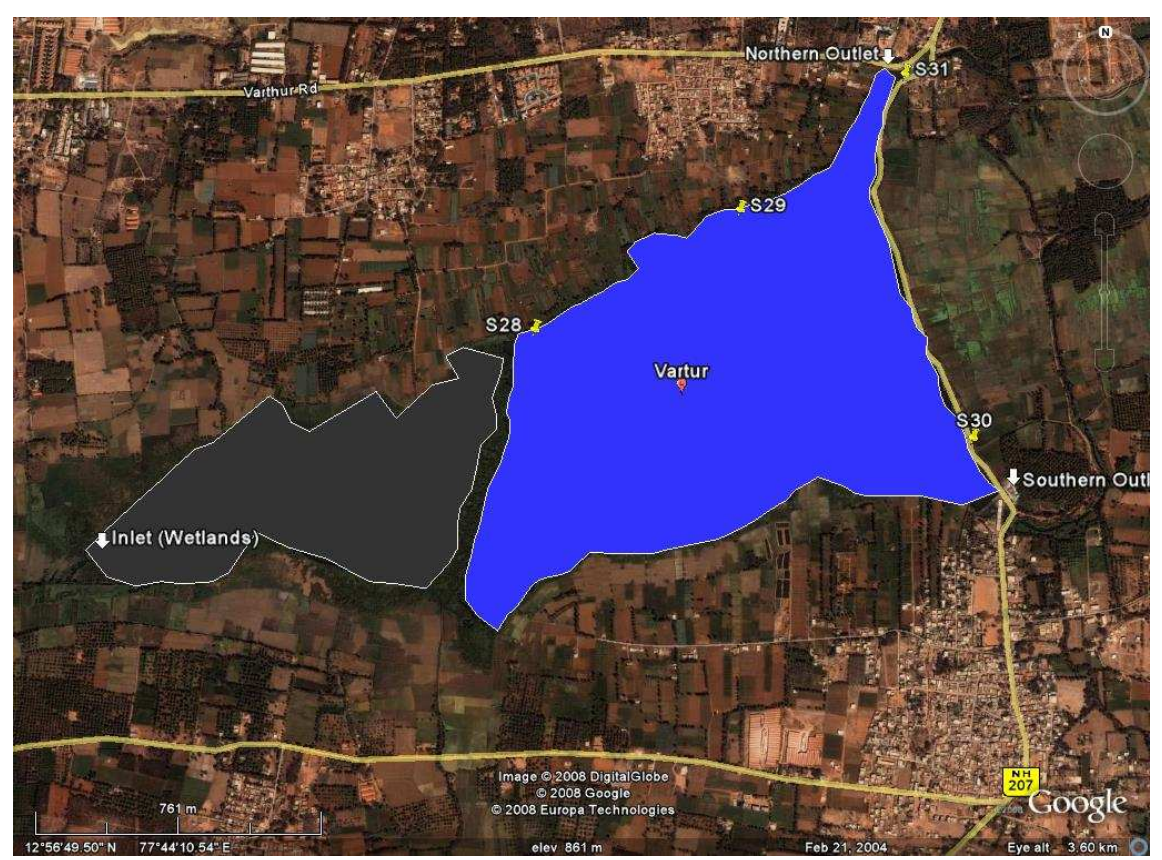

Fig. 1. Satellite imagery of Vartur lake with color imposition.

Digestion of water samples: For digestion of water samples, procedures according to the equipment manual were followed. In this case, $10 \mathrm{ml}$ of a sample was added with $1 \mathrm{ml}$ of conc. $\mathrm{HNO}_{3}$. The solution was put in a reference reaction vessel (a mono-bloc) which was then inserted into a carousel and fitted into a microwave unit ready for digestion. The system was then pre-programmed using the Ethos D control terminal (equipped with SoftWave software) for 5 minutes of microwave digestion at $250 \mathrm{~W}$ power (as per the equipment manual of operation) - left for automatic ventilation after the digestion process for 2 minutes - and then filtered using Whatmann filter paper No. 40. The filtered sample was then made up to $100 \mathrm{ml}$ with metal-free distilled water and stored in a special container ready for analysis.

Digestion of plant samples: For acid digestion of Plant samples, after the samples were first dried in a hot air oven at $105^{\circ} \mathrm{C}$ for 48 hours, they were then ground into fine powder and stored in a plastic bag. Afterwards $0.5 \mathrm{~g}$ of each sample was then added into the reference vessel respectively; subsequently, $4 \mathrm{ml}$ of conc. $\mathrm{HNO}_{3}$ and $0.2 \mathrm{ml}$ of $\mathrm{H}_{2} \mathrm{O}_{2}$ were also added in the reference vessels. The vessels were inserted into their carousels and then into the microwave unit ready for digestion. The microwave digestor was then pre-programmed using the Ethos D control terminal (equipped with Softwave software) for 5 minutes of microwave digestion at $250 \mathrm{~W}$ power and then another 5 minutes of microwave digestion at $500 \mathrm{~W}$ power (as per the equipment manual) - then left for automatic ventilation after the digestion process for 10 minutes - before finally filtered using Whatmann filter paper No. 40 . The filtered sample was then made up to $100 \mathrm{ml}$ with metalfree distilled water and stored in a special container ready for analysis.

Digestion of sediment samples: For digestion of sediment samples, the samples were first dried in a room temperature. The dried samples were then ground into fine powder, sieved with $<2 \mathrm{~mm}$ sieve and stored in a plastic bag. Afterwards, about $0.25 \mathrm{~g}$ of the sample was then added into the reference vessel. Then $2.5 \mathrm{ml}$ of conc. $\mathrm{HNO}_{3}$ and $2.5 \mathrm{ml}$ of $\mathrm{HF}$ acid were added in the reference vessel. The solution was put in a reference reaction vessel which was then inserted into a carousel and into the microwave unit ready for digestion. The system was then pre-programmed using the Ethos D control terminal (equipped with SoftWave software) for 6 minutes of microwave digestion at $300 \mathrm{~W}$ power and then another 5 minutes of microwave digestion at $500 \mathrm{~W}$ power - then left for automatic ventilation after the digestion process for 10 minutes and then filtered using Whatmann filter paper No. 40. The filtered sample was then made up to $100 \mathrm{ml}$ with metalfree distilled water and stored in a special container ready for analysis

Sample analysis: A Shimadzu type Atomic Absorption Spectrophotometer (AAS) 6300 model with Air- $\mathrm{C}_{2} \mathrm{H}_{2}$ flame type of an average fuel flow rate of between 0.8 to $4.0 \mathrm{~L} /$ min and the support gas flow rate between 13.5 to $17.5 \mathrm{~L} /$ min was used for sample analysis. The single element hollow cathode lamps used were of Hamamatsu Photonics 
Table 1. Concentrations of heavy metals in the water of Vartur lake.

\begin{tabular}{|c|c|c|c|c|c|c|c|c|c|c|}
\hline \multirow[b]{2}{*}{ Metal } & \multirow[b]{2}{*}{ Mean } & \multirow[b]{2}{*}{ Range } & \multicolumn{7}{|c|}{$\begin{array}{l}\text { Standard limits and guidelines for drinking water } \\
\text { (in parts per million) }\end{array}$} & \multirow{2}{*}{$\begin{array}{c}\text { CPCB }^{6} \text { Effluent's } \\
\text { Discharge } \\
\text { (Tolerance) } \\
\text { Limits for Inland } \\
\text { Surface Water } \\
\text { (parts per million) }\end{array}$} \\
\hline & & & \multicolumn{2}{|c|}{$\mathbf{B I S}^{1}$} & ICMR $^{2}$ & USEPA $^{3}$ & $\mathrm{FAO}^{4}$ & $\mathrm{WHO}^{5}$ & $\begin{array}{l}\text { Sharma } \\
(2001)\end{array}$ & \\
\hline $\mathrm{Cd}$ & 0.12 & BDL -0.35 & 0.01 & - & 0.001 & 0.01 & - & 0.005 & - & 2.0 \\
\hline Co & 1.89 & BDL- 4.87 & - & - & - & - & 0.01 & - & 1.0 & - \\
\hline $\mathrm{Cr}$ & 2.13 & $0.57-4.07$ & 0.05 & - & - & 0.05 & 0.01 & 0.05 & - & 2.0 \\
\hline $\mathrm{Cu}$ & 0.32 & $0.04-0.59$ & 0.05 & 1.5 & 0.05 & 1.0 & - & 2.0 & - & 3.0 \\
\hline $\mathrm{Mn}$ & 0.02 & BDL -0.09 & 0.1 & 0.3 & 0.5 & 0.05 & 0.2 & 0.05 & 2.0 & 2.0 \\
\hline $\mathrm{Ni}$ & 1.03 & $\mathrm{BDL}-2.66$ & - & - & - & 0.1 & 0.2 & 0.1 & 0.1 & 3.0 \\
\hline $\mathrm{Pb}$ & 2.72 & $0.27-4.78$ & 0.05 & 0.1 & 0.05 & 0.015 & - & 0.01 & - & 0.1 \\
\hline $\mathrm{Zn}$ & 0.25 & $0.03-0.54$ & 5 & 15.0 & - & 5 & 2.0 & 5.0 & - & 5.0 \\
\hline
\end{tabular}

1: Bureau of Indian Standards 2: Indian Council for Medical Research. 3: US Environment Protection Agency

4: Food and Agricultural Organization 5: World Health Organization. 6: Central Pollution Control Board

Co. Ltd - L2433 series. The atomic absorption analysis standards for the given elements were purchased from Inorganic Ventures Inc. and Sisco Research Laboratories Ltd. Calibration curves for various elements obtained from these standards were of first order reaction. The sample for $\mathrm{Cd}, \mathrm{Co}, \mathrm{Cu}, \mathrm{Cr}, \mathrm{Fe}, \mathrm{Mn}, \mathrm{Ni}, \mathrm{Pb}$, and $\mathrm{Zn}$ analysis was aspirated with the help of an Automatic Sampler for Atomic Absorption Spectrophotometer measurement respectively. Series of reference standards - $1 \mathrm{ppm}, 2 \mathrm{ppm}$, $3 \mathrm{ppm}$ - for these metals were prepared from the purchased stock solution manufactured from Sisco Research Laboratories, Mumbai PVT Ltd. The standards were prepared by pipetting $0.1,0.2,0.3, \mathrm{ml}$ respectively of the metal reference standards and made up to $100 \mathrm{ml}$ and mounted on the Automatic sampler for standard calibration curve measurement. Afterwards the samples were injected into the Flame AAS and the reading was directly measured by a computer in $\mathrm{ppm}$. The results were then converted to $\mathrm{mg} / \mathrm{Kg}$.

\section{RESULTS AND DISCUSSION}

The results for concentrations of heavy metals in water, plants, and sediments are represented on Tables 1, 2, and 3 respectively. For sediment geo-accumulation index, the classification table is represented on Table 4. For Pollution Load Index (PLI), the results are presented on Table 5.

Cadmium: Cadmium is a non-essential element that causes kidney damage in humans and negatively affects plant growth and development. It is released into the environment by power stations, heating systems, metal working industries or urban traffic. It is also used in electroplating, pigment, plastic stabilizers, and NickelCadmium batteries. The common source of contaminants is due to corrosion of galvanized pipes, erosion of natural deposits, discharge from metal refineries, run-off from waste batteries and paints. The mean $\mathrm{Cd}$ value in water was $0.12 \mathrm{ppm}$ (BDL-0.35). This exceeded drinking water standards of BIS, USEPA, and WHO. However, the range was within the stipulated CPCB tolerance limit for water bodies subject to pollution discharge (2.0 ppm). In plants, $\mathrm{Cd}$ accumulates in several tissues and complexes with amino acids, organic acids, and other major parts of plant metabolism (Benavides et al.,2005). In the study, the overall mean for $\mathrm{Cd}$ in plants was $8.0 \mathrm{ppm}$. The range was $0.72 \mathrm{ppm}-21.53 \mathrm{ppm}$. The normal range for cadmium in plants is between 0.1 - $2.4 \mathrm{ppm}$ (Maiti, 2003). Dalvi et al. (2007) put the range between $0.01-0.4$ ppm. Also Maiti (2003) put critical concentrations in plants range between $5.0 \mathrm{ppm}-30 \mathrm{ppm}$ while Dalvi et al. put the range at $0.4-$ $2.3 \mathrm{ppm}$. The mean value $\mathrm{Cd}$ value in sediments was 8.66 ppm (BDL - 17.34). This was above the probable effect level of $3.5 \mathrm{ppm}$ (Pascul-Barrera et al.,2004) and over the critical soil concentration range of 3-8 ppm (Maiti,2003)

Cobalt: Cobalt is widely used as alloy for various steels, in electroplating, construction processes including paints, in fertilizers, in porcelain and glass making. In water, Co ranged $\mathrm{BDL}-4.87 \mathrm{ppm}($ Mean $=1.89 \mathrm{ppm})$. This was just above the $1.0 \mathrm{ppm}$ limit reported by Sharma (2001). The overall mean for Co in plants was $28.80 \mathrm{ppm}$. The range was $8.40 \mathrm{ppm}-53.61 \mathrm{ppm}$. The normal range for Co in plants is $0.02 \mathrm{ppm}-1.0 \mathrm{ppm}$. The critical concentration range is $15-50 \mathrm{ppm}$ (Maiti,2003). Results in sediments showed that the mean value was $40.82 \mathrm{ppm}$. The range was $11.68-69.37 \mathrm{ppm}$. This was above the uncontaminated Co range reported by Abbasi et al. (1998). It is interesting to note that the pollution aspects of Cobalt have received much less attention compared to other metals like $\mathrm{Cd}, \mathrm{Zn}, \mathrm{Pb}$, and $\mathrm{Cr}$.

Chromium : As the name Chromium denotes, the first applications were in the colour and pigment but now it is used in a variety of applications such as leather tanning, chromium plating, timber preservation, corrosion 
Table 2. Concentrations of heavy metals in Eichornia crassipes of Vartur lake.

\begin{tabular}{|c|c|c|c|c|c|c|c|c|}
\hline \multirow[b]{2}{*}{ Metal } & \multirow[b]{2}{*}{$\begin{array}{l}\text { Mean } \\
(\text { ppm) }\end{array}$} & \multirow[b]{2}{*}{$\begin{array}{l}\text { Range } \\
(\text { ppm) }\end{array}$} & \multicolumn{3}{|c|}{ Normal range in plants (ppm) } & \multicolumn{3}{|c|}{ Critical range in plants (ppm) } \\
\hline & & & Maiti (2003) & $\begin{array}{l}\text { Dalvi } \text { et al. } \\
\quad \text { (2007) }\end{array}$ & $\begin{array}{c}\text { Abbasi } \\
\text { et al. } \\
(1998)\end{array}$ & Maiti (2003) & $\begin{array}{c}\text { Dalvi } \\
\text { et al. } \\
(2007)\end{array}$ & $\begin{array}{c}\text { Nirmal } \\
\text { Kumar } \\
\text { et al. } \\
(2006) \\
\end{array}$ \\
\hline$\overline{\mathrm{Cd}}$ & 8.0 & $0.72-21.53$ & $0.1-2.4$ & $0.01-0.4$ & - & $5.0-30.0$ & $0.4-2.3$ & - \\
\hline Co & 28.80 & $8.40-53.61$ & $0.02-1.0$ & - & - & $15.0-50.0$ & - & - \\
\hline $\mathrm{Cr}$ & 71.50 & $1.2-160.85$ & $0.03-14.0$ & $1-10$ & - & $5.0-30.0$ & $20-100.0$ & - \\
\hline $\mathrm{Cu}$ & 9.63 & $\mathrm{BDL}-20.95$ & $1-50.0$ & $4.0-15.0$ & $4.0-15.0$ & $5-30.0$ & $20-100$ & $25-90.0$ \\
\hline $\mathrm{Mn}$ & 192.43 & $100.5-306.8$ & $20-100$ & - & - & $300-500$ & - & - \\
\hline $\mathrm{Ni}$ & 47.91 & $26.0-65.32$ & $0.02-5$ & $0.02-5$ & - & $10-100$ & $10-100$ & $10-50$ \\
\hline $\mathrm{Pb}$ & 63.42 & $22.0-98.5$ & $0.2-20$ & $0.1-10$ & - & $30-300$ & $30-300$ & - \\
\hline $\mathrm{Zn}$ & 42.93 & $27.4-58.30$ & $1-400$ & $3-100$ & - & $100-400$ & $100-400$ & - \\
\hline
\end{tabular}

protection, textiles, etc. Around $90 \%$ of leather is tanned using chromium salts. Toxicity of Chromium species is known to cause heritable genetic damage; harmful in contact with skin; and also toxic if swallowed and by inhalation. Cr causes irritation to respiratory system and skin and risk of serious damage to eyes. It is also very toxic to aquatic organisms, may cause long-term adverse effects in the aquatic environment (Darrie, 2001). In water, Cr ranged $0.57-4.07 \mathrm{ppm}$ (Mean: $2.13 \mathrm{ppm}$ ) exceeding the drinking water standards stipulated by BIS, EPA, and irrigation standards limit by FAO. Moreover, Cr exceeded tolerance limit for water bodies subject to pollution which is $2.0 \mathrm{ppm}$. In plants, the mean for $\mathrm{Cr}$ in macrophytes of Vartur Lake was $71.50 \mathrm{ppm}$. The range was $1.20 \mathrm{ppm}-$ $160.85 \mathrm{ppm}$. According to Maiti (2003), the normal range of $\mathrm{Cr}$ in plants should be between $0.03 \mathrm{ppm}-14.0 \mathrm{ppm}$. The critical level range is between $5.00 \mathrm{ppm}-30.0 \mathrm{ppm}$. Dalvi et al. (2007) put the critical range between $20-100$ $\mathrm{ppm}$. Critical concentrations in $\mathrm{Cr}$ in plants are in the range of 5-30 ppm as reported by Maiti (2003). This shows that $\mathrm{Cr}$ in plants in Vartur Lake is in critical range. $\mathrm{Cr}$ in sediments ranged BDL - 21.37 ppm (Mean:10.68 ppm). This was below the probable effect level (PEL) of 90.0 ppm and under the background value of $32.0 \mathrm{ppm}$ reported by Lokeshwari and Chandrappa (2006 a).

Copper: Copper reaches the aquatic environment through wet and dry depositions, mining activities, storm water run-offs, industrial, domestic, and agricultural waste disposal. Among industrial sources include copper plating, pulp and paper mills, e-waste, sewage and other forms of waste waters. The mean $\mathrm{Cu}$ in water was 0.32 ppm (Range: $0.04-0.59$ ppm). Cu was within drinking water standards stipulated by ICMR and EPA, but exceeded BIS limit of $0.05 \mathrm{ppm}$. The overall mean for $\mathrm{Cu}$ in macrophytes of Vartur Lake was $9.63 \mathrm{ppm}$. The range was $\mathrm{BDL}-20.95 \mathrm{ppm}$. The normal range of Copper in plants is $1-50 \mathrm{ppm}$ although it is also reported that the normal range should be $4-15$ ppm (Abbasi et al., 1998). Nirmal et al. (2006) reports the critical range between 25 - 90 $\mathrm{ppm}$. According to Maiti (2003), the normal range of $\mathrm{Cu}$ in plants should be between $5.0 \mathrm{ppm}-20.0 \mathrm{ppm}$. The critical level is between $5.00 \mathrm{ppm}-30.0 \mathrm{ppm}$. Dalvi et al. (2007) reported the normal range for $\mathrm{Cu}$ at $4-15 \mathrm{ppm}$ while the critical range was between $20-100 \mathrm{ppm}$. Cu in plants was largely within the normal range. In sediments, the mean $\mathrm{Cu}$ value was $132.21 \mathrm{ppm}$ (Range: $130.5-134.0 \mathrm{ppm}$ ). This was below the PEL value of 197.0 (Pascul-Barrera et al.,2004). However, the mean exceeded the background value of 27.0 ppm reported by Lokeshwari and Chandrappa (2006 b).

Manganese: Manganese (Mn) is an essential micronutrient throughout all stages of plant development. In humans, it has been implicated in with diseases such as diabetes, nervous instability, convulsions, bone disorders in babies and rheumatoid arthritis (Abbasi et al.,1998). It is important for vital plant functions and act as a cofactor in various enzymes as well as in the structure of chlorophyll. The mean $\mathrm{Mn}$ value in water was $0.02 \mathrm{ppm}$. The range was $\mathrm{BDL}-0.09 \mathrm{ppm}$. This was within the stipulated drinking water standards. The overall mean for Mn in plants was $192.43 \mathrm{ppm}$. The range was $100.51-306.84 \mathrm{ppm}$. This range was within the critical plant concentration range of $300-500$ ppm reported by Maiti (2003). In sediments, Mn ranged 112.0 - $167.0 \mathrm{ppm}$. The mean value was 139.36 ppm.

Nickel : Nickel is used extensively in Nickel plating and alloy manufacture. High nickel alloys are used in chemical, marine, electrical, oil refining, and other industrial processes. In water, $\mathrm{Ni}$ mean was $1.03 \mathrm{ppm}$. The range was BDL $-2.66 \mathrm{ppm}$. This was above drinking water standards stipulated for Nickel (Ni). But the mean was within the tolerance limit for water bodies subjected to pollution discharge. Similarly, Ni has been found in a variety of plants and ranges up to $340 \mathrm{ppm}$ have been recorded non-edible wild plants. In benthic Algae of fresh water lakes, Ni concentrations have ranged between $52-$ 
Table 3. Concentrations of heavy metals (ppm) in the bed sediments of Vartur lake.

\begin{tabular}{|c|c|c|c|c|c|c|c|}
\hline Metal & $\begin{array}{l}\text { Mean } \\
(\text { ppm) }\end{array}$ & $\begin{array}{l}\text { Range } \\
(\text { ppm) }\end{array}$ & $\begin{array}{c}\mathbf{C P C B}^{1} \\
(2001)\end{array}$ & $\begin{array}{c}\text { PEL } \\
\text { Barrera } \\
\text { et al. }(2004)\end{array}$ & $\begin{array}{l}\text { Background } \\
\text { Values } \\
\text { (Lokeshwari } \\
\text { and } \\
\text { Chandrappa } \\
\text {,2006) }\end{array}$ & $\begin{array}{c}\text { Uncontamin } \\
\text { ated } \\
\text { Sediments } \\
\text { (Abbasi } \text { et al, } \\
\text { 1998) }\end{array}$ & $\begin{array}{l}\text { Critical Soil } \\
\text { Concentration } \\
\text { (Maiti, 2003) }\end{array}$ \\
\hline $\mathrm{Cd}$ & 8.66 & $\mathrm{BDL}-17.34$ & BDL & 3.5 & - & - & $3-8$ \\
\hline Co & 40.52 & $11.68-69.37$ & - & - & - & $4.7-20.0$ & $25-50$ \\
\hline $\mathrm{Cr}$ & 10.68 & BDL-21.37 & 389.3 & 90.0 & 32.0 & $12-44$ & $75-100$ \\
\hline $\mathrm{Cu}$ & 132.21 & $130.52-134$ & 113.0 & 197.0 & 27.0 & - & $60-125$ \\
\hline $\mathrm{Mn}$ & 139.36 & $112-167.0$ & 225.2 & - & - & - & $1500-3000$ \\
\hline $\mathrm{Ni}$ & 42.04 & $16.2-68.0$ & 54.5 & 35.9 & 23.0 & $1-20.0$ & 100 \\
\hline $\mathrm{Pb}$ & 46.5 & $4.43-88.5$ & 64.9 & 91.0 & 10.0 & $2-50.0$ & $100-400$ \\
\hline $\mathrm{Zn}$ & 123.0 & $25.71-220.25$ & - & 315.0 & 51.0 & $1-50$ & $70-400$ \\
\hline
\end{tabular}

74 ppm (Abbasi et al.,1998). Small amounts of Ni may be beneficial to plants and its plant toxicity varies in magnitudes according to plant species. Cases of $\mathrm{Ni}$ poisoning in plants include dwarfing or repression of growth (Sharma,2001). The overall mean for $\mathrm{Ni}$ in macrophytes of Vartur lake was $47.91 \mathrm{ppm}$. The range was $25.91-65.32 \mathrm{ppm}$. This is in critical category of $\mathrm{Ni}$ contents in plants as described by Nirmal et al. (2006) which is between $10-50 \mathrm{ppm}$. In sediments, the mean value for $\mathrm{Ni}$ was $42.04 \mathrm{ppm}$. The range was $16.2-68.0 \mathrm{ppm}$. This shows that $\mathrm{Ni}$ exceeded the probable effect level (PEL) reported by Pascul-Barrera et al. (2004).

Lead: Lead $(\mathrm{Pb})$ can exist in several valences and are of critical environmental importance. In urban areas, the principal source of $\mathrm{Pb}$ in wetlands comes from gasoline additives, metal plating, e-waste and battery cells, electrical equipment, textile mills, dye and pigments, paper mills, chemical and fertilizer industries, and ghee manufacturing industries (Abbasi et al.,1998). Lead toxicity leads to anaemia both by impairment of haemoglobin biosynthesis and acceleration of red blood cell destruction in human beings. Lead also depresses sperm count (Anglin-Brown et al., 1995). The mean $\mathrm{Pb}$ value in water was $2.72 \mathrm{ppm}$. The range was $0.27-4.78 \mathrm{ppm}$. This range exceeded the drinking water standards and effluent discharge limits prescribed by CPCB. Nevertheless, Lead $(\mathrm{Pb})$ has been known to accumulate in aquatic macrophytes in considerable levels based on the rooted and floating species. Lead's concentration ranging from $0.1-10.0 \mathrm{ppm}$ has been known to inhibit growth of small macrophytes and algae. The critical range for $\mathrm{Pb}$ as described by Nirmal et al. (2006) and Maiti (2003) is 30 - $300 \mathrm{ppm}$. The overall mean for $\mathrm{Pb}$ in macrophytes of Vartur Lake was $63.42 \mathrm{ppm}$. The range was $21.98-98.44 \mathrm{ppm}$. In the sediments, results showed a mean value of $46.5 \mathrm{ppm}(\mathrm{PEL}=91.0)$. However, the $\mathrm{Pb}$ concentration in Vartur Lake exceeded the background value for uncontaminated sediments reported by Lokeshwari and Chandrappa (2006 a).
Zinc : Zinc in urban lake water is caused by a variety of industrial effluents including phosphates fertilizers, Ghee Manufacturing, Metal Processing Units, Zinc Plating Industries, Silver plating industries, distillery units, landfill leachates, urban storm water, fly ashes of coal powered plants, poultry sewage, and compost (Abbasi et al.,1998). The $\mathrm{Zn}$ concentration in water ranged $0.03-0.59 \mathrm{ppm}$. The mean $\mathrm{Zn}$ value was $0.25 \mathrm{ppm}$. This was within the stipulated drinking water standards by BIS, ICMR, EPA, and irrigation limits by FAO. The overall mean for $\mathrm{Zn}$ in macrophytes of Vartur Lake was $42.93 \mathrm{ppm}$. The range was $27.44-58.27 \mathrm{ppm}$. This range did not exceed the critical concentration range in plants of $100-400 \mathrm{ppm}$ reported by Maiti (2003). In sediments, the range for $\mathrm{Zn}$ was $25.71-220.28 \mathrm{ppm}$ which was below the PEL limit of 315.0 reported by Pascul-Barrera et al. (2004). The mean $\mathrm{Zn}$ value was $123.0 \mathrm{ppm}$ which was above the 51.0 reference background value reported by Lokeshwari and Chandrappa (2006 b).

Plant/Water bioaccumulation factor (BAF) : Studies of Bioaccumulation of heavy metal contaminants in aquatic macrophytes help us measure the degree and the extent to which various species of a wetland ecosystem are exposed to metal contaminants and how much of those contaminants are absorbed by these plant species. The plant BAF shows largely the chemical dynamics of inflow and outflow of the fresh water within that wetland ecosystem. It is to be noted here that in determining the metal accumulation in plants from its fresh water body, a number of factors have been included in making out such a trend. Firstly, the issue of the degree and extent of exposure of that wetland system by anthropogenic activities; the size of the wetland, the flushing effect of the basin depending upon the sufficient or erratic rainfalls, the life cycle of an exposed plant species and even the age of the sampled plant species from that sampling point. The results show that Manganese had the highest BAF value (9621.50) while Cobalt had the lowest (15.24). The metal bioaccumulation trend was as follows: Mn (9621.50) 
Table 4. Classification of sediment geo-accumulation index.

\begin{tabular}{ccl}
\hline Sediment geo-accumulation index & Class & \multicolumn{1}{c}{ Classification of contamination } \\
\hline$<0$ & 0 & Practically uncontaminated \\
$>0-1$ & 1 & Practically Uncontaminated to Moderate Contamination \\
$>1-2$ & 2 & Moderate Contamination \\
$>2-3$ & 3 & Moderate Contamination to Strong Contamination \\
$>3-4$ & 4 & Strong Contamination \\
$>4-5$ & 5 & Strong Contamination to Very Strong Contamination \\
$>5$ & 6 & Very Strong Contamination \\
\hline
\end{tabular}

Source: Lokeshwari \& Chandrappa (2006)

Table 5. Classification of sediment geo-accumulation index.

\begin{tabular}{ccl}
\hline Metal species & $\begin{array}{c}\text { Sediment } \\
\text { geoaccumulation index }\end{array}$ & \multicolumn{1}{c}{ Classification of contamination } \\
\hline $\mathrm{Cd}$ & 0.5 & Practically uncontaminated to moderate contamination \\
$\mathrm{Co}$ & 0.3 & Practically uncontaminated to moderate contamination \\
$\mathrm{Cr}$ & 0 & Practically uncontaminated \\
$\mathrm{Cu}$ & 1.18 & Moderate contamination \\
$\mathrm{Mn}$ & 1.54 & Moderate contamination \\
$\mathrm{Ni}$ & 0.20 & Practically uncontaminated to moderate contamination \\
$\mathrm{Pb}$ & 1.12 & Moderate contamination \\
$\mathrm{Zn}$ & 0.47 & Practically uncontaminated to moderate contamination
\end{tabular}

$>\mathrm{Zn}(171.72)>\mathrm{Cd}(67)>\mathrm{Ni}(46.51)>\mathrm{Cr}(33.57)>\mathrm{Cu}(30)>$ $\mathrm{Pb}(23.32)>\mathrm{Co}$ (15.24). As reported by Lokeshwari and Chandrappa (2006 a), the accumulation of a particular metal is compared with the presence of that metal in the lake water. It is therefore significant to note that although $\mathrm{Mn}$ was least available metal in the lake water $(0.02 \mathrm{ppm})$ its bioaccumulation factor was the highest. The same pattern can be inferred for Co which is more available in water (1.89 ppm) but has the lowest accumulation factor.

Plant/Sediment metal concentration ratio: The plantsediment metal concentration ratio trend in Vartur lake was as follows: $\mathrm{Cr}(6.69)>\mathrm{Mn}(1.38)>\mathrm{Pb}(1.36)>\mathrm{Ni}$ (1.14) $>\mathrm{Cd}(0.92)>\mathrm{Zn}(0.35)>\mathrm{Co}(0.71)>\mathrm{Cu}(0.07)$. This indicates that $\mathrm{Cr}, \mathrm{Mn}, \mathrm{Pb}$ and $\mathrm{Ni}$ were more available in the plant system of the lake than in the surrounding sediments. It is interesting here to note that $\mathrm{Cr}$ had the highest plant/ sediments metal concentration factor even though its bioavailability in plants (71.5 ppm) was lower compared to Manganese (192.3 ppm).

Sediment geo accumulation index (GeoI): This is a quantitative check of metal pollution in aquatic sediments. It is calculated as follows: $\mathrm{GeoI}=\ln \left[\mathrm{Cn} / 1.5^{*} \mathrm{Bn}\right]$ where " $\mathrm{C}$ " is the measured metal concentration and " $\mathrm{B}$ " is a compared background value (reference). Different countries employ their own respective values for "background levels" in relation to the existing environmental conditions that reflect their surroundings.
Lokeshwari and Chandrappa (2006 b) have attempted to use background levels of Vasanthapura Lake for five elements namely $\mathrm{Fe}$ (6571 ppm), Zn (51 ppm), Cu (27 ppm), $\mathrm{Ni}(23 \mathrm{ppm})$, and $\mathrm{Pb}(10 \mathrm{ppm})$. The reference levels used in this study attempts to include both the local reference values, the universally agreed Probable Effect Level (PEL) values above which contamination might occur for aquatic life $(\mathrm{Cd}=3.5 \mathrm{ppm})$, background values for Co $(20.0 \mathrm{ppm})$ reported by Abbasi et al. (1998) and the normal Mn range in soils reported by Maiti (2003).

The Sediment Geo-accumulation Index in Vartur lake reveals that $\mathrm{Cr}$ pollution in the sediments was practically uncontaminated $(\mathrm{GeoI}<0)$ with Class 0 , whereas $\mathrm{Cd}, \mathrm{Zn}$, $\mathrm{Co}$ and Ni ranged between uncontaminated to moderate contamination ( $>0-1$ ) at Class 1 with the Sediment Geoaccumulation Index ranging from $0.5,0.47,0.30$, and 0.20 respectively. Manganese $(\mathrm{Mn})$, Copper $(\mathrm{Cu})$ and Lead $(\mathrm{Pb})$ recorded moderate sediment contamination level (> 1-2) at Class 2 level ranging from 1.54, 1.18, and 1.12 respectively. These findings indicate that based on the Sediment Geo-accumulation Index, all metals with the exception of Chromium are at the level of moderate sediment contamination. This trend still poses the risk of enhanced bioaccumulation of these metals up the food web. (See Table 5).

Heavy metal pollution load index in Vartur lake: Pollution Load Index (PLI) is used in order to find out the mutual 
effect of the different studied metals. According to ElSammak (2001), PLI is calculated as follows:

$$
\begin{aligned}
& \mathrm{PLI}=\left(\mathrm{CF}_{\mathrm{Cd}} \mathrm{XCF}_{\mathrm{Co}} \mathrm{XCF}_{\mathrm{Cr}} \mathrm{XCF}_{\mathrm{Cu}} \mathrm{XCF}_{\mathrm{Mn}} \mathrm{XCF}_{\mathrm{Ni}} \mathrm{XCF}_{\mathrm{Pb}} \mathrm{X}\right. \\
& \mathrm{CF}^{1 / 8}
\end{aligned}
$$

$\mathrm{CF}$ is the contamination factor whose value is obtained by dividing the concentration of metals in sediments divided by their respective background values. Here, the background values for $\mathrm{Cr}, \mathrm{Cu}, \mathrm{Ni}, \mathrm{Pb}$ and $\mathrm{Zn}$ were obtained from Lokeshwari and Chandrappa (2006); Cd (Pascul Barrera et al., 2004), Co (Abbasi et al.,1998), and Mn (Maiti,2003). The results show that the pollution load index of Vartur Lake was 2.41. This index can be used to compare the extent of contamination by similar metal species to other lakes.

\section{Conclusion}

Cadmium (Cd), Cobalt (Co), Chromium (Cr), Nickel (Ni), and Lead $(\mathrm{Pb})$ all exceeded drinking water standards. Cobalt was compared to the tolerance limit reported by Sharma (2001). However only Chromium (Cr) exceeded the CPCB's tolerance limits for water bodies subjected to effluent discharge. In case of aquatic plants (Eichornia crassipes), Cadmium (Cd), Cobalt (Co), and Chromium (Cr) were above the maximum limit of the critical range (Maiti,2003). Nickel (Ni) was considered above critical concentration range reported by Nirmal et al. (2006). Zinc $(\mathrm{Zn})$ and Copper $(\mathrm{Cu})$ were within normal concentration ranges. In the sediments, Cadmium (Cd) and Nickel (Ni) exceeded the Probable Effect Level (PEL) reported by Pascul Barrera et al. (2004) respectively. Nevertheless, $\mathrm{Cd}$ concentration was above the critical range in soils reported by Maiti (2003). Apart from Manganese (Mn), the bioaccumulation between metals did not display much variation and the trend followed: $\mathrm{Mn}(9621.50)>\mathrm{Zn}$ $(171.72)>\mathrm{Cd}(67)>\mathrm{Ni}(46.51)>\mathrm{Cr}(33.57)>\mathrm{Cu}(30)>\mathrm{Pb}$ (23.32) > Co (15.24). Mn was more bio-available while Co was the least. Sediment Geo-accumulation Index registered moderate sediment contamination with $\mathrm{Mn}, \mathrm{Cu}$, and $\mathrm{Pb}$ having more deposition compared to $\mathrm{Cd}, \mathrm{Zn}, \mathrm{Co}$, and $\mathrm{Ni}$. Cr had the highest plant/sediments metal concentration factor even though its bioavailability in plants $(71.5 \mathrm{ppm})$ was lower compared to Manganese (192.3 ppm). Pollution Load Index for Vartur was 2.41.

\section{REFERENCES}

Abbasi, S.A., Naseema Abbasi, Soni, Rajendra (1998). Heavy metals in the environment, Mittal publications.

APHA (1995). Standard methods for the examination of water and waste water. 19th ed., American Public Health Association, Washington.

Anglin-Brown, B., Armour-Brown, A. and Lalor, G.C. (1995). Heavy metal pollution in Jamaica 1: Survey of cadmium, lead and zinc concentrations in the Kintyre and Hope Flat districts; Journal of Environmental Geochemistry and Health, 17: 51-56.
Baron, G., Brun, S., Grière, A.S., Metz, S. and Boursier, B. (2004). Microwave digestion for rapid radiostrontium analyses in salmon fishbone; Journal of Radioanalytical and Nuclear Chemistry, 260, (2) 283-289.

Benavides, Maria P., Susanna M. Gallego, Maria L. Tomaro (2005) Cadmium Toxicity in Plants; Brazilian Journal of Plant Physiology, 17(1):21-34.

Bergstrom, J.C. and Stoll, J.R. (1990). Economic Value of Wetlands Based Recreation; Journal of Ecological Economics, 2: 129-147.

Bifano, C, and Mogollon, J.L. (1995). Metallic contaminant profiles in sediment cores from Lake Valencia, Venezuela; Journal of Environmental Geochemistry and Health, 17:113118.

Burton, K.W. and John, E. (1977). A study of heavy metal contamination in the Rhondda Fawr, South Wales; Water, Air, and Soil Pollution; 7:45-68.

Canadian Environmental Protection Act (1999). Part 4. Pollution Prevention.

Dalvi, Kapil M., Vikas, V. Vaidya, M.B. Kekare, , Sunita Shailajan and Ashish Pawar (2007). Effect of regional variation on heavy metal content of Mallotus philippensis using AAS technique. Nature, Environment, and Pollution Technology, 6 (4):653656.

Darrie, Grant (2001). Commercial Extraction Technology and Process Disposal in the Manufacture of Chromium Chemicals from Ore, Environmental Geochemistry and Health, 23: 187193.

Das, J. and Acharya, B.C. (2003). Hydrology and Assessment of Lotic Water Quality In Cuttack City, India; Water, Air, and Soil Pollution; 150 :163-175.

El-Sammak, A. (2001). Heavy Metal Pollution in Bottom Sediment, Dubai, United Arab Emirates. Bull. Environ. Contam. Toxicology, 67:295-302.

Farago, M.E. and Mehra, A. (1989).A preliminary investigation of pollution in the River Yamuna, Delhi, India: metal concentrations in river bank soils and plants; Journal of Environmental Geochemistry and Health; July 1989;

Gopal, G.V., Rajashekar, N. and Geetha, R. (2002). Lake Biodiversity of Macrophytic Plant Groups: A Case Study (Kukkarahalli Lake), In Proceedings of Symposium on Restoration of Lakes and Wetlands (Lake 2002), Center for Ecological Sciences, Indian Institute of Science, Bangalore.

Ikem, A., Egiebor, N.O. and Nyavor, K. (2003) Trace Elements In Water, Fish And Sediment From Tuskegee. Lake, Southeastern USA, Water, Air, and Soil Pollution, 149: 51-75.

Jafari, N. (2007). Ecological Role of Aquatic Plants in Freshwater Lakes, (In) Proceedings of the 12th World Lake Conference, Jaipur-India, 28th October - 2nd November 2007, Ministry of Environment and Forests, Government of India, New Delhi, pp 201.

Jose L. Mogollon, Armando J. Ramirez, Robert B. Guilen and Claudio Bifano (1989). Heavy metals and organic carbon in sediments from the Tuy River basin, Venezuela: Journal of Environmental Geochemistry and Health, 12 : 277.

Karmakar, Ashmita (2007). Conservation and restoration Adi Ganga Through Practices. (In) Proceedings of the 12th World Lake Conference, Jaipur-India, 28th October - 2nd November 2007, Ministry of Environment and Forests, Government of India, New Delhi, pp 47. 
Kronfeld, J. and Navrot, J. (1975). Aspects of Trace Metal Contamination in the coastal rivers of Israel, Water, Air, and Soil Pollution, 4 : 127-134.

Lokeshwari, H. and Chandrappa, G.T. (2006 a). Heavy metals content in water, water hyacinth and sediments of Lalbagh tank, Bangalore (India). Journal of Environmental Science and Engineering, 48 (3): 183-188.

Lokeshwari, H. and Chandrappa, G.T. (2006 b). Impact of heavy metal contamination of Bellandur Lake on soil and cultivated vegetation. Current Science, 91(5):622 - 627.

Maiti, S.K. (2003). Handbook of Methods in Environmental Studies - Vol.2: Air, Noise, Soil and Overburden Analysis, ABD Publishers.

McGee, Chandra J., Fernandez, Ivan J., Norton, Stephen A., Stubbs and Constance, S. (2007). Cd, Ni, Pb, and Zn concentrations in forest vegetation and soils in maine, Water, Air and Soil Pollution, 180: 141-15.

Nadkarni, R. A. (1984). Applications of microwave oven sample dissolution in analysis. Analytical Chemistry, 56:2233-2237.

Nouri M. Hassan, Pat E. Rasmussen, Ewa Dabek-Zlotorzynska, Valbona Celo and Heidi Chen (2007). Analysis of environmental samples using microwave- assisted acid digestion and Inductively coupled plasma mass spectrometry: maximizing total element recoveries, Water, Air and Soil Pollution; 178: 323-334.

Neto, Jose Antonio Baptista; Mirian Crapez, John J. McAlister, and Claudia Gutterres Vilela (2005). Concentration and Bioavailability of Heavy Metals in Sediments from Niteroi Harbour (Guanabara Bay/S.E. Brazil), Journal of Coastal Research, 21 (4):811-817.

Nirmal Kumar, J.I Hiren Soni, and Rita N. Kumar (2006). Biomonitoring of selected freshwater macrophytes to assess lake trace element contamination: a case study of Nal Sarovar Bird Sanctuary, Gujarat, India, J. Limnol., 65(1): 9-16.
Pascual-Barrera, A., Gold-Bouchot, G., Ceja-Moreno, V. and del Rýo-Garcý'a, M. (2004). Heavy metals and hydrocarbons in sediments from three Lakes from San Miguel, Chiapas, Mexico Bull. Environ. Contam. Toxicol., 73:762769.

Pillotte, James O., Winchester, John W., and Glassen, Robert C. (1978). Detection of heavy metal pollution in estuarine sediments; Water, Air, and Soil Pollution; 9: 363-368.

Phuong, P.K., Son,C.P.N, Sauvain, J. and Tarradellas, J. (1998) Contamination by PCB's, DDT's, and heavy metals in sediments of Ho Chi Minh city's canals, Viet Nam; Bull. Environ. Contam. Toxicol,60:347-354.

Sandroni, V., Smith, C. M., and Donovan, A. (2003). Microwave digestion of sediment, soils and urban particulate matter for trace metal analysis. Talanta, 60: $715-723$.

Satyasiba Bedamatta (2007). Ecological and Institutional Understanding of Chilika Lagoon. In : Lakes and Coastal Wetlands - Conservation, Restoration and Management; Mohanty, P.K. (eds); Capital Publishing Company; pp 358381.

Sharma, B.K. (2001). Environmental Chemistry $-6^{\text {th }}$ Revised Edition; GOEL Publishing House.

Singh, Munendra; Müller, German; and Singh, I. B. (2002) Heavy metals in freshly Deposited Stream Sediments of Rivers Associated With Urbanisation of the Ganga Plain, India. Water, Air and Soil Pollution, 141 : 35-54.

Tanja Ducic and Andrea Polle (2005). Transport and detoxification of manganese and copper in plants; Brazilian Journal of Plant Physiology; 17(1): 103-112.

Vardanyan, L., Schmieder, K., Sayadyan, H., Heege, T., and Heblinski Agyemang, T. (2007). Heavy metal accumulation by certain aquatic macrophytes from Lake Sevan (Armenia). In : Proceedings of the 12th World Lake Conference, JaipurIndia; 28th October - 2nd November 2007; Ministry of Environment and Forests, Government of India, New Delhi; pp 6. 